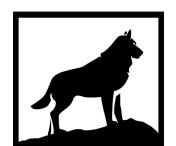

Michigan Technological

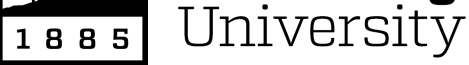

Michigan Technological University Digital Commons @ Michigan Tech

URBAN EVAPOTRANSPIRATION IN WATER SCARCE REGIONS ESTIMATES FOR THE MIDDLE RIO GRANDE BASIN, UNITED STATES AND MEXICO

Jessica Alger

Michigan Technological University, jlalger@mtu.edu

Copyright 2019 Jessica Alger

Recommended Citation

Alger, Jessica, "URBAN EVAPOTRANSPIRATION IN WATER SCARCE REGIONS ESTIMATES FOR THE MIDDLE RIO GRANDE BASIN, UNITED STATES AND MEXICO", Open Access Master's Thesis, Michigan Technological University, 2019.

https://doi.org/10.37099/mtu.dc.etdr/943

Follow this and additional works at: https://digitalcommons.mtu.edu/etdr

Part of the Environmental Engineering Commons 


\title{
URBAN EVAPOTRANSPIRATION IN WATER SCARCE REGIONS \\ ESTIMATES FOR THE MIDDLE RIO GRANDE BASIN, UNITED STATES AND MEXICO
}

\author{
By \\ Jessica Alger
}

\begin{abstract}
A THESIS
Submitted in partial fulfillment of the requirements for the degree of MASTER OF SCIENCE

In Environmental Engineering
\end{abstract}

MICHIGAN TECHNOLOGICAL UNIVERSITY

2019

(C) 2019 Jessica Alger 
This thesis has been approved in partial fulfillment of the requirements for the Degree of MASTER OF SCIENCE in Environmental Engineering.

\section{Department of Civil \& Environmental Engineering}

Thesis Advisor: $\quad$ Dr. Alex Mayer

Committee Member: Dr. Ann Maclean

Committee Member: $\quad$ Dr. David Watkins

Department Chair: $\quad$ Dr. Audra Morse 


\section{Table of Contents}

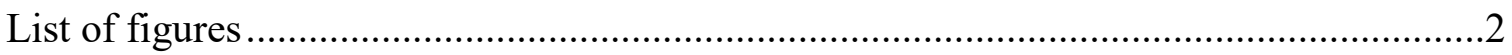

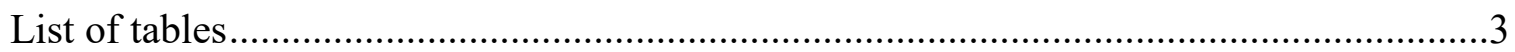

Preface

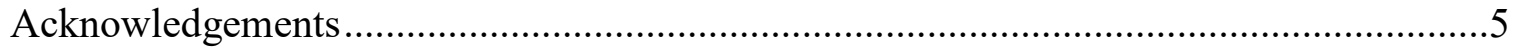

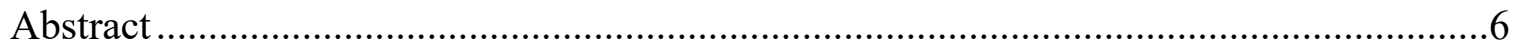

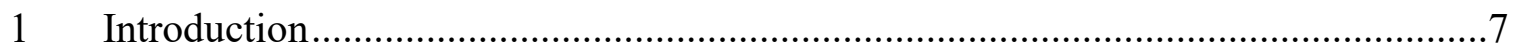

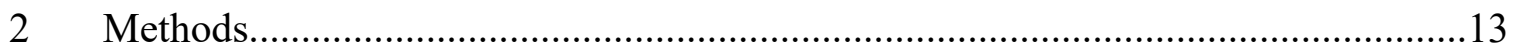

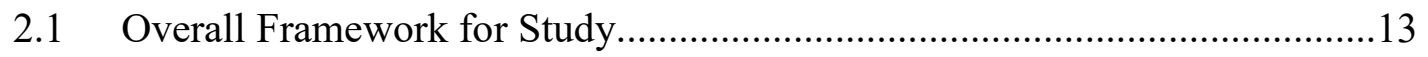

2.2 Independent Estimation of Urban ET Components: Evaporation from Open Water .................................................................... 14

2.3 Independent Estimation of Urban ET Components: Evaporation from

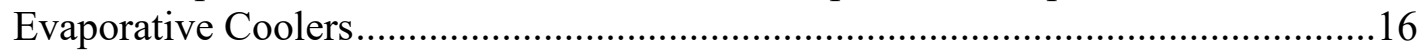

2.4 Independent Estimation of Urban ET Components: Evaporation from

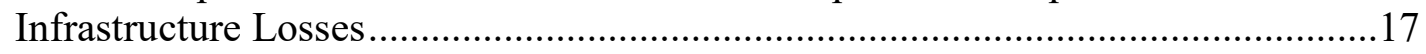

2.5 Independent Estimation of Urban ET Components: Evapotranspiration from

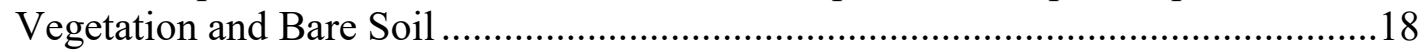

2.6 Estimation of Total Urban ET based on Consumptive Water Use..................20

2.7 Estimation of Total Urban ET based on Seasonal Water Use.........................21

2.8 Estimation of Urban ET Rates based on Urban Land Area ………………....22

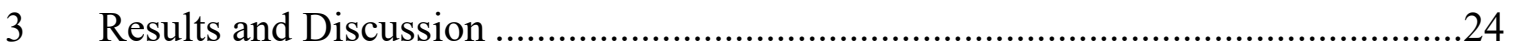

3.1 Total Urban ET by City and Method........................................................24

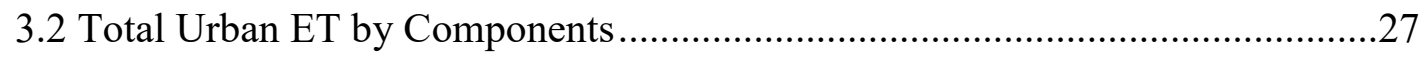

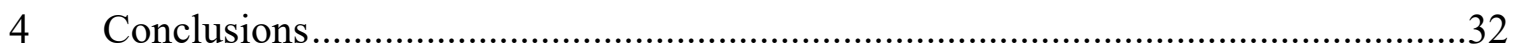

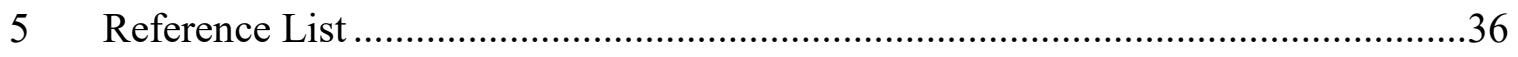

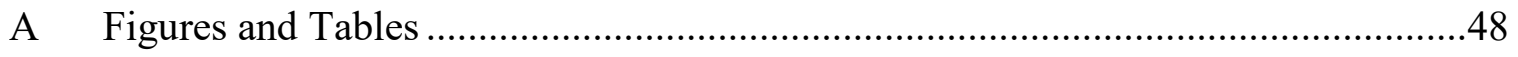

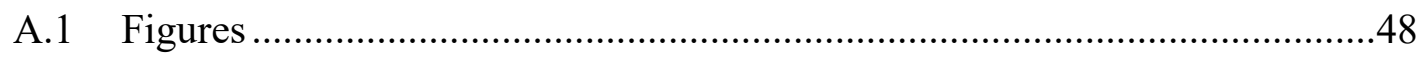

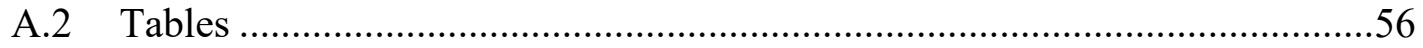




\section{List of figures}

Figure 1. Middle Rio Grande study area including the cities of Las Cruces, New Mexico, US; El Paso, Texas, US; and Ciudad Juarez, Chihuahua, MX.

Figure 2. Urban ET map for January, 2015, using the Operational Simplified Surface Energy Balance (SSEBop) developed by the USGS for the Rio Grande basin. ET maps obtained from the USGS were clipped to the city borders for Las Cruces, NM, US; El Paso, TX, US; and Ciudad Juarez, CH, MX to obtain urban ET for the Middle Rio Grande basin study area.

Figure 3. Urban ET map for July, 2015, using the Operational Simplified Surface Energy Balance (SSEBop) developed by the USGS for the Rio Grande basin. ET maps obtained from the USGS were clipped to the city borders for Las Cruces, NM, US; El Paso, TX, US; and Ciudad Juarez, CH, MX to obtain urban ET for the Middle Rio Grande basin study area.

Figure 4. Simplified water pathway for Las Cruces, NM, USA, showing how water is traced from the urban water source to the wastewater treatment plant effluent use.

Figure 5. Average total urban water demand and non-evapotranspirative water demand, million cubic meters per month from 1993-2015.

Figure 6. Average urban water demand, cubic meters per capita per month 1993-2015. .53

Figure 7. Annual evapotranspiration comparison in million $\mathrm{m} 3$ for each city, 2001-2015. To compare annual changes in urban ET, average ET from all methods was used. ET totals include ET from infrastructure losses.

Figure 8. Average annual evapotranspiration comparison of urban ET components in million cubic meters, 1993-2015. 


\section{List of tables}

Table 1. Summary of climate and demographic data for each city in the Middle Rio

Grande study area. .56

Table 2. Average annual comparison of ET methods in million cubic meters, 1993-2015. Lower range of ET assumes zero evaporation from infrastructure losses and upper ranges assumes $100 \%$ evaporation from infrastructure losses................................56

Table 3. Average annual ET and average overall water demand comparison in cubic meters per capita, 1993-2015.

Table 4 Average annual comparison of ET rates for each method in millimeters, 19932015. Lower range of ET assumes zero evaporation from infrastructure losses and upper ranges assumes $100 \%$ evaporation from infrastructure losses......................57 


\section{Preface}

The following manuscript has been co-authored by myself, Alex Mayer, Saurav Kumar (Texas A\&M University) and Alfredo Granados Olivas (Autonomous University of

Ciudad Juarez). I am responsible for developing the ET estimation framework, gathering the relevant data and images, performing the ET calculations, leading the writing of the manuscript drafts, and preparing the tables and figures. 


\section{Acknowledgements}

I would like to express my thanks to my thesis advisor, Dr. Alex Mayer, who gave me the opportunity to work on the Middle Rio Grande research project and whose guidance, encouragement, and support helped me to develop my knowledge and skills as a graduate student.

I would like to sincerely thank my committee members, Dr. Ann Maclean and Dr. David Watkins for devoting time and effort to provide me with insight and valuable feedback on my research and thesis.

I would also like to thank my partner, Jon, and our wonderful children; Eric, Darien, Ryan and Violet for their support, patience and encouragement during my many hours of time spent on research and preparing my thesis.

Finally, I would like to acknowledge the funding sources for my education and research: The Civil and Environmental Engineering Department at Michigan Technological University and the United States Department of Agriculture (award number 2015-6800723130). 


\section{Abstract}

Urban evapotranspiration (ET) in semi-arid and arid regions is an important component of the urban water cycle, especially in regions that have limited freshwater supplies. Understanding urban evapotranspiration in these regions is necessary for assessing and managing water resources and ensuring that conservation strategies are effective and sustainable. The objective of this study is to estimate urban ET in the Middle Rio Grande Basin to provide an understanding of evaporative water losses in semi-arid to arid urban environments for future water management decisions. The focus of this study is on the cities of El Paso, TX, US; Las Cruces, NM, US; and Ciudad Juarez, $\mathrm{CH}, \mathrm{MX}$.

Components of urban ET include vegetation and bare soil ET, open water evaporation, evaporation from infrastructure losses, and evaporative cooler evaporation. Multiple methods were used to provide an estimate of total urban ET from individual components, as well as total ET for each city at an average annual time scale. Average urban ET for the study area, including evaporation from precipitation, is approximately $500 \mathrm{~mm}$ annually. Urban ET accounts for up to $60 \%$ of annual water demand and ranges from an average of 13 million $\mathrm{m}^{3}$ annually in Las Cruces to 91 million $\mathrm{m}^{3}$ annually in El Paso. Water conservation and management is crucial in water scarce environments, especially as urban populations increase and freshwater supplies continue to decrease in many regions along with shifts in climate. Water loss to ET is an important component of the urban water cycle and must be considered in conservation and management decisions for urban water supplies to remain sustainable in the future. 


\section{Introduction}

Evapotranspiration (ET) accounts for $40 \%$ to $70 \%$ of water losses from urban water use (Litvak, 2016; St. Hilaire, 2008) and is a crucial component in the urban water cycle and water balances (Kurc, 2004; Litvak, 2013), especially in regions that are facing water scarcity from increasing water demands and decreasing freshwater supplies (Pataki et al., 2011). Understanding the role of urban evapotranspiration in semi-arid to arid environments and effectively estimating the total amount of urban evapotranspiration in these regions is important for water resource management and conservation, especially as populations continue to increase, shifts in climate become more pronounced, and water resources become more variable. Over the last century, global water demand has been increasing at rates that are double the rate of increases in population (FAO, 2019). World population projections suggest that approximately $70 \%$ of the world's population will be living in urban areas by 2050, which will place increased demand on urban water resources (FAO, 2019; United Nations Department of Economic and Social Affairs, 2018).

Water scarcity, increased groundwater depletion and loss of agricultural land are predicted to continue to increase along with population growth and shifts in climate (United Nations, 2019), causing concerns of freshwater depletion in already water scarce regions. Over two billion people currently live in water scarce regions, and by the year of 2030, water scarcity and shifts in climate may cause displacement of up to 700 million people in semi-arid and arid regions across the world (United Nations, 2018). Population and water use projections escalate concerns of water scarcity, especially in regions that 
already have water use limitations. Understanding where water can be conserved is crucial for future water sustainability in these regions.

Multiple methods have been used historically to estimate ET, including ground measurements (Grimmond \& Oke, 1999; Nouri et al., 2016; Peters, et al., 2011), water balance methods (Al-Kofahi et al, 2012; Cleugh et al., 2005; Grimmond \& Oke, 1999), potential ET estimates using meteorological data (Hargreaves \& Samani, 1985; Mcmahon et al., 2013; Samani, 2000; FAO, 2019) and remote sensing (Nouri et al., 2014; Senay, 2018). Although multiple methods have been used to successfully estimate evapotranspiration for agricultural areas, the heterogeneity of urban land use and cover makes it difficult to estimate urban ET using traditional ET methods (Anderson \& Vivoni, 2016; Grimmond \& Oke, 1999; Litvak et al., 2017; Qiu, 2017). Using a combination of methods to estimate urban ET helps to reduce errors in estimations and provides a more accurate overall representation of urban ET, including the drivers and components that affect urban ET rates (Allen et al, 2011; Kim \& Kaluarachchi, 2018; Reitz et al., 2017).

The complexity of urban landcover and ecosystems along with the multiple factors that contribute to evapotranspiration rates leads to challenges in quantifying urban ET at a city scale (Litvak et al., 2017). Urban ET rates are affected by metrological variables, changes in vegetation types and landscapes, and urban infrastructure. Traditional methods of estimating urban ET are often time consuming, and the required climatological data is difficult to obtain, especially over large historical time periods (Al-Kofahi, 2012; Hargreaves, 1985; Litvak, 2017). Urban ET is not as widely studied as crop and natural 
vegetation ET (Litvak, 2016; Raoufi \& Beighley, 2017) but makes up a significant component of the overall water cycle and needs to be considered for more accurate estimates of regional water losses from evapotranspiration.

Many of the traditional ET models were designed to estimate ET for crops and natural vegetation but do not apply as well to the unique landscapes and land cover of urban environments (Al-Kofahi, 2012; Nouri, 2016; Xie, 2009). Agricultural crops are generally comprised of one crop type with the same overall ET rate, and cover a large area with little to no impermeable surface, whereas urban landscapes are much more heterogeneous. The heterogeneity of urban ground cover (i.e. pavement, different soil types, variability in irrigation, exotic plant species, etc.) contributes to the complexity of estimating urban ET (Grimmond and Oke, 1999; Nouri, 2014). Previous research suggests that available ET estimation methods show variance in the accuracy of ET estimates and often contain uncertainty and biases in calculations for urban ET (Allen, 2011; Auilar, 2018; Litvak, 2013). Previous research also suggests that traditional methods of estimating ET are not as reliable for estimating ET in regions with semi-arid to arid climates (Samani et al., 2005, Skaggs \& Samani, 2005).

Ground measurements of evapotranspiration from instruments including lysimeters, eddy covariance towers and flux towers can give accurate point measurements of ET that are useful for validating and providing insights on controlling factors as well as calibrating urban ET equations and methods. Although useful for ET studies, ground measurements are often difficult to obtain for large areas, do not capture spatial variability and can have uncertainties caused by calibration errors and measurement 
biases over long time periods (Allen et al, 2011; Reitz, 2017). Ground measurement devices are often expensive to install and maintain, making widespread use inefficient and ground measurements impractical to use for city scale ET measurements. Variation in urban landscapes and landcover contributes to inaccuracies when upscaling ground measurements to estimate evapotranspiration for entire urban areas (Jiang, 2016, Peters, 2011).

Water balance methods can be used to constrain urban ET by considering each component of the urban hydrological cycle (Cleugh et al., 2005; Mitchell et al., 2001) but may not account for spatial variability in urban landscapes (Al-Kofahi et al., 2012), and are most often used to estimate total urban ET without providing estimates for individual urban ET components. Evapotranspiration equations based on meteorological data can be used to estimate potential urban ET when accurate meteorological data is available. Obtaining accurate and complete meteorological data often makes estimating potential ET using climate variables difficult over larger time periods.

Multiple remote sensing models are available to estimate ET and can be processed for large scales, making remote sensing a common method for ET estimation. Remote sensing models are most commonly used for agricultural ET estimates and large areas of continuous vegetation. Satellite images are taken periodically, may not be usable due to cloud cover or satellite position and can be difficult to obtain for large study periods (Allen et al., 2011). The uncertainties involved with measuring urban ET and the multiple contributing variables in semi-arid and arid environments makes using a combination of 
ET measurement methods necessary for obtaining the most accurate results (Litvak, 2013).

The main components of urban ET are: land surface evaporation and transpiration from urban vegetation, evaporation from open water, evaporation from infrastructure losses and evaporation from evaporative cooling (Cleugh et al., 2005; DeOreo et al., 2011; Grimmond \& Oke, 1999; Jiang \& Weng, 2016; Liu et al., 2010; Qui et al., 2013). Urban vegetation is comprised of areas of vegetation that are irrigated with municipal water including residential and commercial landscaping, golf courses and parks. Open water evaporation is comprised of evaporation from swimming pools, golf course ponds and any other open water areas that are supplied or maintained with municipal water supplies. Infrastructure losses include leaks from piping systems from the source of water to water treatment plants, to residential and commercial users and to wastewater treatment plants. Evaporative cooler evaporation includes the sum of water that is lost due to evaporation for the purpose of cooling the air.

Despite interest in urban ET in semi-arid and arid environments, to our knowledge there have been very few studies that have attempted to estimate urban wide ET in semiarid and arid environments. The majority of urban ET research is focused on one urban ET component and larger, less complex areas of urban environments. The purpose of this study is to estimate urban evapotranspiration in the Middle Rio Grande basin, with focus on the cities of Las Cruces, New Mexico, United States; El Paso, Texas, United States; and Ciudad Juarez, Chihuahua, Mexico with a total population of 2.3 million. The Middle Rio Grande basin has a semi-arid to arid climate with an average annual rainfall of 230 
mm. Pumping rates for urban areas in the Middle Rio Grande basin exceed recharge rates and combining increased pumping with shifts in climate has resulted in changes in watershed dynamics, water scarcity and water rights conflicts (Hibbs et al, 2003; Sheng \& Devere, 2005). Urban areas in Middle Rio Grande basin have water use limitations because annual precipitation is not sufficient in these regions to recharge aquifers and water from irrigation often does not infiltrate deep enough into the soil to reach the groundwater aquifers. The current study uses a combination of methods to estimate urban ET in the Middle Rio Grande basin. 


\section{Methods}

\subsection{Overall Framework for Study}

The three cities in the study area are located in the middle Rio Grande basin (see Figure 1). A summary of climate and demographic data for each city in the Middle Rio Grande study area is found in Table 1. The current study focuses on the three largest cities within the middle Rio Grande basin. Smaller cities in the study area were neglected because of their substantially smaller populations. Texas counties in the middle Rio Grande basin include El Paso County and Hudspeth County with a combined population of 703,640. The city of El Paso has a population of 683,577 , accounting for $97 \%$ of the total population. New Mexico counties in the middle Rio Grande basin include Dona Ana County and Sierra County with a total population of 226,700. The city of Las Cruces has a population of 101,712 and the next largest city has a total population of 14,600 .

In this work, urban evapotranspiration in each city is separated into evaporation from open water ( $E$, water), evaporation from evaporative cooling ( $E$, cool), evaporation from infrastructure losses (E, losses) and evapotranspiration from vegetation and bare soil $(E T, v e g)$. Three approaches are used to estimate total urban ET and ET components for each city in the study area: a) independent estimation and summing of each urban ET component based on the analysis of remotely sensed data and water utility data (ET, ind); b) estimation of total urban ET based on consumptive use as derived from water utility data (ET, cuse); and c) estimation of total urban ET based on seasonal water use as derived from water utility data (ET, season). Each of these approaches is based on simplifying assumptions and has its own intrinsic uncertainties, as explained in the 
following sections. Urban ET was estimated monthly for the study period of 1993-2015, which captures a broad range of climate conditions, including years with above and below average temperatures and precipitation. Urban ET results are presented at an average annual time scale based on the results of the monthly ET estimates.

\subsection{Independent Estimation of Urban ET Components: Evaporation from Open Water}

Open water evaporation includes evaporation from swimming pools, golf course ponds and other small urban ponds. Open water evaporation was estimated based on historical pan evaporation data, pan evaporation coefficients, an evaporation model and the surface area of open water. Monthly pan evaporation was obtained from weather stations in each city. Since $15 \%$ of the total months in the study period were missing pan evaporation data, the Hargreaves and Samani model was used to substitute for observations in the missing months (Hargreaves, G. H., \& Samani, Z. A, 1985). The Hargreaves and Samani Equation requires minimum climatology data, making it a practical method for modeling ET. Although the Hargreaves and Samani model is used primarily for estimating crop evapotranspiration, calibrating the model to pan evaporation data will provide reasonably accurate estimates of open water evaporation (Mcmahon et al., 2013; USBR ET Toolbox, 2018).

The Hargreaves and Samani model is:

$$
E T=K_{E T} R_{A} T D^{0.5}(T C+17.8)
$$


where $K_{E T}$ is a calibration coefficient, $R_{A}$ is extraterrestrial radiation (mm/day), $T D$ is the mean maximum temperature minus the mean minimum temperature $\left({ }^{\circ} \mathrm{C}\right)$, and $T C$ is the mean temperature $\left({ }^{\circ} \mathrm{C}\right)$. Extraterrestrial radiation is calculated using a formula that utilizes the latitude of each city and the day of the year (Hargreaves, G. H., \& Samani, Z. A, 1985). The calibration coefficient $\left(K_{E T}\right)$ for each city was calibrated using daily pan evaporation data observations from 1993-2015 at the climate stations in each city (Gobierno de MÉXICO, nd; NOAA, nd; TWDB, nd; WRCC, nd). The calibration coefficients for each city are: El Paso $K_{E T}=0.00382$, Las Cruces $K_{E T}=0.00358$ and Ciudad Juarez $K_{E T}=0.00338$. $\mathrm{R}^{2}$ values for the calibrations ranged from 0.73 to 0.88 .

The surface area of urban open water was calculated using Google Earth Engine (GEE) and ArcGIS analysis of remote sensing imagery. The imagery that was used for open water processing included NAIP imagery obtained from the Texas Natural Resources Information System (TNRIS, nd) and the USDA Geospatial Data Gateway (USDA, nd) with one-meter spatial resolution, Landsat imagery from USGS EarthExplorer (USGS, nd) with a thirty-meter spatial resolution and World Imagery base maps (ESRI, 2018). NAIP imagery was available every two years starting in 2004 for El Paso and 2009 for Las Cruces and Ciudad Juarez. It was necessary to estimate open water for missing years based on Landsat imagery, available NAIP years, annual changes in city boundaries and historical population data. To quantify total areas of urban open water using Google Earth Engine, an algorithm was developed based on NDVI and color thresholds. This algorithm was successful in delineating $90 \%$ of small open water areas less than $1200 \mathrm{~m}^{2}$. Small areas that were not likely to be open water were eliminated by 
assuming a threshold radius of $5.0 \mathrm{~m}$. Shadows were reduced by using a transformation on red color. Open water polygons determined from the GEE algorithm were checked visually using ArcGIS to eliminate false positives and delineate false negatives. Open water areas greater than $1200 \mathrm{~m}^{2}$ were delineated by hand.

Monthly evaporation estimates for open water were determined by multiplying the total open water area by the pan evaporation observations or modeled pan evaporation. Given the shallow nature of the open water in the three cities, it was assumed that the open water evaporation was equivalent to pan evaporation and a pan coefficient of one was applied for this study.

\subsection{Independent Estimation of Urban ET Components: Evaporation from Evaporative Coolers}

Evaporative coolers are commonly used in arid and semi-arid climates for air conditioning during the warmer months as an alternative to refrigerated cooling. Since detailed information on household use and consumptive water use of evaporative coolers in the three cities is unavailable, water use for evaporative coolers was estimated for each city based on results of literature, expert opinion and census data. Water use from evaporative coolers for residential use in El Paso was estimated as $42 \mathrm{~m}^{3}$ per household annually for a $186 \mathrm{~m}^{2}$ house (Tarquin, 2013). The New Mexico Office of the State Engineer estimates that 47 to $60 \mathrm{~m}^{3}$ of water per household is used annually for a $139 \mathrm{~m}^{2}$ house in Las Cruces for evaporative cooling (NMOSE, nd). The average house size in the United States is $200 \mathrm{~m}^{2}$ (US Census Bureau, 2010) versus $131 \mathrm{~m}^{2}$ in Mexico (UN Population Division, 2019). 
To estimate evaporation from evaporative coolers, it was assumed that $70 \%$ of houses in El Paso (Tarquin, 2013) and Las Cruces used evaporative cooling prior to 2013, and 50\% of houses after 2013 (L. Larocque, personal communication, June 29, 2019; A. Tarquin, personal communication, June 24, 2019), with $42 \mathrm{~m}^{3}$ of water use per household annually. For Ciudad Juarez, evaporative cooling water use is estimated at $53 \mathrm{~m}^{3}$ per household annually, and the assumption that $75 \%$ of households used evaporative cooling over the entire study period was used. It was also assumed that evaporative coolers are used from May through September in each city.

\subsection{Independent Estimation of Urban ET Components: Evaporation from Infrastructure Losses}

Infrastructure water losses include water distribution and wastewater collection system leaks. Annual infrastructure water losses for Las Cruces and El Paso were determined from water audits and water utility data. E1 Paso infrastructure losses were available for 2010 to 2017 from El Paso Water Utility water loss audits. Previous years were estimated using an average loss percentage of all known years. Las Cruces infrastructure losses were available annually for 2000-2005 and 2010-2017 from Las Cruces Water Utility water audit reports and the remaining years were estimated using an average loss percentage from all known years. Infrastructure water losses for Ciudad Juarez were not available at an annual basis and were estimated at $20 \%$ of total water demand for the entire study period (Servicios de Ingeniería e Informática, 2013).

Adequate data is not available for the fate of water from infrastructure losses (groundwater recharge or evaporative), and for this study it is therefore assumed that 
infrastructure losses are either $0 \%$ or $100 \%$ evaporative and are presented as a range in urban ET results. Water from slow leaks in infrastructure is likely evaporated from soil or used by vegetation and transpired, especially when water tables are lower than urban water infrastructure and the rate at which water would return to underground aquifers does not exceed the rate that water evaporates in semi-arid to arid climates. Further research is necessary to determine percentages of evaporative losses from infrastructure losses to accurately determine ET from infrastructure losses.

\subsection{Independent Estimation of Urban ET Components: Evapotranspiration from Vegetation and Bare Soil}

To estimate urban ET from vegetation and bare soil, the Operational Simplified Surface Energy Balance (SSEBop) approach was used to construct monthly ETa (actual evapotranspiration) maps for each of the three cities in the study area. SSEBop maps for the Upper Rio Grande River Basin were obtained from the USGS SSEBop Evapotranspiration: Early Warning and Environmental Monitoring Program (Senay et al., 2018). Monthly actual evapotranspiration totals for the Upper Rio Grande River Basin (1984-2015) were calculated by the USGS using the SSEBop model to quantify and map total ET using Landsat images and the associated weather datasets (Senay et al., 2018). ET maps obtained from the USGS were clipped to the three urban boundaries within the current study area to construct monthly ET maps using the USGS calculated ET data. The SSEBop data was analyzed on a monthly time scale from 1993-2015 using ArcGIS 10.6 for each of the three study area cities. SSEBop urban ET maps for January 2015 and July 2015 are shown in Figure 2 and Figure 3. 
ET totals from the SSEBop calculations include ET from precipitation and open water, making it necessary to subtract precipitation and open water totals from the monthly ET totals to obtain urban vegetation and bare soil ET estimates. Given total ET from SSEBop results and evaporation totals from precipitation and open water, it was possible to estimate ET from vegetation and bare soil using the following equation:

$$
E T_{\text {SSEBop }}=E T_{\text {veg }}+E_{\text {water }}+E_{\text {precip }}
$$

City boundaries were obtained from Paso del Norte Mapa and the Texas Natural Resources Information System (PdnMapa, nd; TNRIS, nd). City boundaries were edited in ArcGIS to remove natural areas not irrigated with urban water and agricultural districts based on satellite imagery and water utility service area boundaries to obtain a more accurate estimate of urban evapotranspiration. Irrigation canal images from satellite imagery were used to help verify agricultural areas within urban boundaries. Agricultural areas were easy to separate for Las Cruces and Ciudad Juarez, as they were confined to areas near the Rio Grande River. Defining urban boundaries for El Paso is more complicated due to agricultural areas within residential sections of the urban boundaries. Urban development over the 1993-2015 study period made it necessary to consider land use changes annually, and urban borders were modified accordingly at an annual time scale to capture changes from agricultural to urban land use with the assumption that urban borders did not change at a monthly time scale.

Linear features caused by scan line correction errors with the Landsat 7 sensor were present in $20 \%$ of SSEBop images. Linear features were filled by interpolation from 
temporally adjacent images by USGS (Senay, G., personal communication, July 2, 2019) and were therefore included in the annual SSEBop ET totals with the assumption that the linear features appear at different times in different locations and therefore provided accurate estimates at an annual scale.

\subsection{Estimation of Total Urban ET based on Consumptive Water Use}

To estimate consumptive use ET, urban water use data was collected from the water utility companies and categorized to ensure that water user categories were equal for each

city. Water pathways were traced from the water source to the wastewater treatment plant effluent users. Water pathways included urban water sources, water treatment plants, urban water users, wastewater treatment plants, and wastewater treatment plant effluent users. A sample water pathway for Las Cruces is shown in Figure 4. Consumptive water use in each city was assumed to be equal to total urban ET, assuming that water contained in products exported from and other minor consumptive uses in the cities are negligible. Modeling and extrapolation were used to fill gaps from missing water utility data using water use coefficients and known data from water utilities, water audits, water utility annual reports, and annual population data.

Consumptive water use calculations were based on water utility data on monthly surface and groundwater extractions; residential, commercial, and industrial urban water use; wastewater effluent, and infrastructure losses. Water utility bulk water sales to and wastewater from communities outside of the study area were eliminated from the urban areas consumptive use estimates. Water used for industrial cooling, irrigation of urban 
landscapes (schools, parks, golf courses), and unbilled purposes such as firefighting and street cleaning were assumed to be $100 \%$ evaporative. Infrastructure losses are presented as a range from $0 \%$ to $100 \%$ evaporative. Self-supplied water and associated wastewater data was not readily available for each city and was not included in urban consumptive use estimates. Recycled wastewater effluent used for industrial cooling and irrigation of parks, schools and other irrigated areas within the cities were included in urban consumptive use. Recycled wastewater data was available from El Paso and Las Cruces water utilities. Wastewater for Ciudad Juarez is used for urban irrigation as well as agricultural irrigation. Percentages of known wastewater urban reuse for Ciudad Juarez are assumed to be $100 \%$ evaporative and the unknown percentages of wastewater use are assumed $100 \%$ agricultural and are not included in the urban ET estimates.

\subsection{Estimation of Total Urban ET based on Seasonal Water Use}

Monthly water utility data was analyzed to separate evapotranspirative water use from non-evapotranspirative water use, based on the assumptions that a) water used in December, January and February (“cool” season) for each year was for nonevapotranspirative water use (primarily indoor use) only, b) the monthly nonevapotranspirative water use was constant through the year, c) the difference between non-evapotranspirative water use and wastewater treatment plant effluent during the cool season accounts for infrastructure losses and evapotranspirative water use that is not seasonal (industrial cooling, mining, etc.) and d) evapotranspirative water use can be calculated by subtracting the constant non-evapotranspirative water use from the total use for the months of March through November ("warm" season). This assumption implies 
that irrigation and evaporative cooler use occur only during the warm season and that evaporation from open water is negligible during the cool season. Wastewater treatment plant effluent contributes to overall urban evapotranspiration when used for industrial processes and irrigation of urban vegetation.

Seasonal water use ET estimates calculate urban ET based on differences in monthly water demand and to estimate total urban ET it is necessary to add wastewater treatment plant effluent for evapotranspirative water use to seasonal water use estimates. The separation of the months into a cool season (December to February) and a warm season (March to November) were justified with a $t$-test analysis of monthly water use in all three cities over the study period. The mean water use for the months of December, January and February were found to be similar at a 5\% confidence level and the mean water use for February vs. March as well as November vs. December were found to be different at a $<1 \%$ confidence level. In addition, when mean wastewater effluent for the three cities for December, January and February were compared to mean wastewater effluent for the remainder of the year, the means over the two seasons were found to be equal with a $<1 \%$ confidence level, confirming that there is no significant difference in wastewater effluent seasonally and implying that monthly indoor water use is relatively constant.

\subsection{Estimation of Urban ET Rates based on Urban Land Area}

Urban areas were estimated as the area served by the respective water utilities in the three cities. These areas were determined every year by taking the areas within the 
political boundaries for each city (see Table 1) and subtracting undeveloped areas that appeared to consist of natural vegetation and thus were unlikely to be served by the water utilities. The undeveloped areas were determined with a Google Earth Engine (GEE) algorithm that uses Landsat $5 \& 7$ images and National Land Cover Database (NLCD) data to train a classifier to estimate developed urban land areas served by water utilities of each city. The NLCD, created by the Multi-Resolution Land Characteristics (MRLC) Consortium, provides land cover and land cover change data for the United States at a 30 $\mathrm{m}$ resolution (MLRC, nd). The GEE algorithm is based on the assumption that urban areas served by water utilities fall within four NLCD classification: developed open space; developed, low intensity; developed, medium intensity; and developed, high intensity. The GEE algorithm was successful in delineating $>90 \%$ of developed urban areas when compared to El Paso and Las Cruces NLCD maps. 


\section{Results and Discussion}

\subsection{Total Urban ET by City and Method}

Table 2 presents a comparison of average annual urban ET in million $\mathrm{m}^{3}$ for each city in the study area. The fate of water from urban infrastructure losses is not widely studied, and insufficient data to calculate the total amount of water that evaporates from infrastructure losses makes it necessary to present the results as a possible ET range with $0 \%$ or $100 \%$ of infrastructure losses included in evaporative totals. The totals from each ET method are relatively similar for each city, indicating that the annual ET estimates for the three cities are robust. Although Ciudad Juarez has a substantially higher population (see Table 1), El Paso and Ciudad Juarez have similar upper range ET estimates. If infrastructure losses are not included in ET totals, average annual ET for Ciudad Juarez is significantly lower than El Paso. Las Cruces has the smallest overall annual ET for the study area, which can be explained by small land area compared to El Paso and Ciudad Juarez.

Table 3 presents ET results in $\mathrm{m}^{3}$ per capita for each ET method and average annual total $\mathrm{m}^{3}$ per capita water demand. Based on $\mathrm{m}^{3}$ per capita, El Paso and Las Cruces have similar ET and total demand per capita, both of which are roughly twice that for Ciudad Juarez. The much lower per capita demand for Ciudad Juarez explains why the total ET for Ciudad Juarez and El Paso are similar, even though the population of Ciudad Juarez is roughly twice that of El Paso. Based on water demand for the current study period,

annual $\mathrm{m}^{3}$ per capita water demand is $235 \mathrm{~m}^{3}$ for El Paso, $283 \mathrm{~m}^{3}$ for Las Cruces and 135 
$\mathrm{m}^{3}$ for Ciudad Juarez. Average water use per capita is based on total urban water demand, and annual ET per capita is a significant portion of overall water demand per capita.

On average, the United States per capita public water consumption is $135 \mathrm{~m}^{3} \mathrm{yr}^{-1}$, New Mexico water consumption is $148 \mathrm{~m}^{3} \mathrm{yr}^{-1}$ (CSG, 2018), Texas water consumption is $152 \mathrm{~m}^{3} \mathrm{yr}^{-1}$ (USGS, 2018), average Mexico water consumption is $134 \mathrm{~m}^{3} \mathrm{yr}^{-1}$ (Gobierno de MEXICO, 2015) and water consumption for the northwest region of Mexico is $103 \mathrm{~m}^{3}$ $\mathrm{yr}^{-1}$ (National Water Commission, 2017). Differences in per capita water consumption may arise from factors including availability of fresh water, differences in water use regulations and income disparities between cities.

Figure 5 presents average monthly water demand in million $\mathrm{m}^{3}$ per month for each city, with non-evaporative baselines based on average January, February and December water use. Figure 6 presents average monthly water demand per capita for each city. These results show that the differences between cool weather water use (during January, February and December) and warm weather water use (March through November) are substantial for each city, but the fraction of warm weather use for Ciudad Juarez is substantially smaller than that of the US cities. This result underscores the results in Table 3, where it is shown that the fraction of ET out of total water use and per capita total demand are much lower for Ciudad Juarez. Seasonal water use estimates assume that the average water use in January, February and December is the baseline for nonevaporative use for each month and can be used to determine the evaporative water use for March through November. Previous research suggests that warm weather water use accounts for $40 \%$ to $70 \%$ of urban water use in semi-arid and arid climates (DeOreo, 
2011; Litvak et al., 2016; Mini et al., 2014; St. Hilaire et al., 2008), which suggests that the results for the current study area are reasonable.

Figure 7 presents the average annual evapotranspiration for each city in million $\mathrm{m}^{3}$ from 2001-2015 to show variability in ET at an annual time scale. Annual ET estimates in Figure 7 present annual urban ET using the assumption that infrastructure losses are $100 \%$ evaporative. The same temporal trends are seen when infrastructure losses are not included in ET totals. The years with lower ET correspond primarily to the low, imported surface water availability years of 2003-2005 and 2012-2014 and, to a lesser extent, years with higher local precipitation. Understanding the effects of climate and water availability on urban evapotranspiration is important for future predictions of urban ET and its role in urban water management.

Table 4 presents the average annual evapotranspiration rate for each city in $\mathrm{mm}$ from 1993-2015. Based on ET rates in mm, Las Cruces has the lowest annual average ET rate and El Paso and Ciudad Juarez have higher, but similar annual average ET rates when comparing ET without infrastructure losses. It is surprising to see that Ciudad Juarez water use is higher than El Paso by observing per capita ET and multiple factors may contribute to similarities and differences between the cities.

Similar lower range ET rates between El Paso and Ciudad Juarez can be explained by observing ET rates from individual components. Vegetation ET is the largest component for each city and comparing the overall vegetation coverage and vegetation ET for each city helps to explain the similarities for El Paso and Ciudad Juarez. El Paso 
and Ciudad Juarez have similar overall vegetation ET as well as similarities in large vegetation areas including parks, golf courses, sports fields and urban drainage areas. Large vegetation areas are irrigated with municipal water, self-supplied water from private wells and wastewater treatment plant effluent. Self-supplied well water is not accounted for in urban ET estimates, due to lack of total self-supplied well water use data for each city. Water from infrastructure losses may also contribute to vegetation and bare soil ET. Las Cruces has the smallest vegetation ET, which helps to explain why overall ET rates for Las Cruces are smaller than El Paso and Ciudad Juarez.

Accounting of wastewater treatment plant effluent to irrigation is imperfect and may play a role in urban vegetation ET differences between cities. Differences in water use behavior driven by conservation for the three cities may also contribute to differences in urban ET rates, but more research is necessary to determine annual changes in water use behavior. Finally, SSEBop ET analysis has been shown to work well for agricultural ET

estimates but has not been widely used for urban ET estimation. The complexity of urban ET, urban land areas and water use behaviors between the three cities contribute to similarities and differences in ET rates.

\subsection{Total Urban ET by Components}

A comparison of individual ET components in million $\mathrm{m}^{3}$ at an average annual scale is presented in Figure 8. Vegetation and bare soil ET is the largest ET component for each city and accounts for 88-92\% of total component ET for El Paso, 76-91\% for Las Cruces and 55-81\% for Ciudad Juarez. After vegetation and bare soil, infrastructure 
losses and evaporative cooling are the next largest components of urban ET for each city. Infrastructure losses are highest for Ciudad Juarez and account for 32\% of urban ET if considered $100 \%$ evaporative. Open water evaporation accounts for $2 \%$ of total urban ET for El Paso and Las Cruces and less than 1\% of total urban ET for Ciudad Juarez. Of the four main urban ET components, open water evaporation is the smallest contributor for each city.

Several assumptions on urban evaporative water use were made when estimating individual ET components. Commercial and public urban vegetation is irrigated with a combination of treated water from water utilities, wastewater treatment plant effluent and water from self-supplied wells. Self-supplied water data was not readily available and therefore was not included in total ET estimates but likely contributed to vegetation and bare soil totals from remote sensing. Self-supplied water users also likely have septic systems for wastewater discharge, which would be partially evaporative. Wastewater treatment plant effluent reuse data was not readily available for each city, and only known totals to urban evaporative uses were included in urban ET estimates. If the end user for wastewater treatment plant effluent was unknown, it was assumed nonevapotranspirative. In Ciudad Juarez, wastewater effluent is commonly used for agricultural purposes but for the purpose of estimating urban irrigation, the wastewater effluent used agriculturally was not added to the urban ET estimates. Wastewater effluent data in Ciudad Juarez was not available prior to the year of 2000 and likely contributed a significant amount to urban ET, but without adequate data, it was not included in urban ET estimates. 
To estimate urban ET from vegetation and bare soil, urban boundaries were determined annually. Urban boundaries include the area of each city that is within the water utility service area and small cities that receive water and treat wastewater using the city water utility. There was ambiguity when determining urban boundaries in areas of cities that were mixed urban and agricultural use, which may have led to underestimation of vegetation and bare soil ET.

Infrastructure losses can account for a significant portion of total urban water use. Understanding the fate of water from infrastructure losses is important in understanding the magnitude of evaporative water loss from aging and insufficient infrastructure. The fate of water from urban infrastructure losses is not widely studied, and insufficient data to calculate the total amount of water that evaporates from infrastructure makes it necessary to present the results as a possible ET range. It is likely that small, constant leaks do not infiltrate deep enough into the soil to contribute to groundwater recharge in semi-arid to arid climates and are evaporated from the soil or used by vegetation. Water from large leaks, for example pipe breaks, is likely to be a combination of evaporation and runoff that may result in surface water recharge. If infrastructure losses are evaporative, it is likely that the results from SSEBop would include evaporative water from infrastructure losses. Due to insufficient data on infrastructure losses, the assumption that leaks are not included in SSEBop evaporative totals was used. This assumption may lead to an overestimation of vegetation and bare soil ET. Future studies on infrastructure losses, recharge and evaporation are necessary to accurately estimate ET from infrastructure losses. 
Ciudad Juarez has a large percent of infrastructure losses due to aging and insufficient infrastructure (Chavez, 2000; Quadri De La Torre, 1999). Infrastructure loss data is not available annually for Ciudad Juarez and was assumed as $20 \%$ of water demand for the entire study period. Ciudad Juarez infrastructure losses were reported as $15 \%$ to $50 \%$ of urban water supply in previous studies (Chavez, 2000; Salas Plata Mendoza, 2014), and using an estimate of $20 \%$ for each month throughout the study period may be under or over estimating urban ET from infrastructure losses. Infrastructure losses are often more prevalent in months with increased water demand, and pipe breaks would cause a large increase in the amount of water lost to infrastructure losses. If water from leaks is considered runoff, the water would likely run off to irrigation canals and evaporative losses would be present. Insufficient data on the fate of water from infrastructure losses adds uncertainty to ET estimates from leaks.

Evaporation from evaporative cooling is not widely studied, and estimates for evaporative cooling may be underestimates as a result of the assumptions used for the current study. The number of months that households use evaporative cooling and the efficiency of evaporative coolers varies, but insufficient data on evaporative cooling made it necessary to assume set months of use and efficiency for the entire study period. For the current study it is assumed that evaporative coolers are used from May through September and the remaining months have zero evaporative losses from evaporative coolers. The number of households using evaporative cooling is estimated for each city and the household sizes remain constant for the current study. Evaporative cooling as an individual component of urban ET focuses on residential cooling and does not include 
commercial and industrial cooling due to lack of data available for the study area. Evaporative cooling is common in semi-arid to arid regions, and further research is necessary to determine urban water lost to evaporation from evaporative cooling in semiarid to arid regions, especially as populations increase and climate projections predict future climate shifts.

Open water area was calculated annually and used to calculate monthly evaporation with the assumption that open water area remains constant at an annual scale. Open water types between cities vary, with El Paso and Las Cruces having a larger percentage of swimming pools and urban ponds than Ciudad Juarez. On average, swimming pools are $43 \%$ of open water in El Paso, $65 \%$ in Las Cruces and $7 \%$ in Ciudad Juarez. In the original Hargreaves and Samani equation, a calibration coefficient of 0.0023 is used, and this calibration coefficient has been used in previous literature for New Mexico and Texas (Al-Kofahi, 2012; Henggeler, 1996), but for the purpose of this study the coefficient was calibrated to pan evaporation data for each city for more accurate open water evaporation results. Given the shallow nature of the open water in the three cities, it was assumed that the open water evaporation was equivalent to the pan evaporation when estimating open water evaporation, which may result in overestimates. The Hargreaves and Samani method is based on historical climate data and may not be as effective in estimating urban ET in the future due to predicted shifts in climate. Despite issues that arise when estimating evaporation from open water, it is a very small component of overall urban ET and does not change significantly if different assumptions are used. 


\section{Conclusions}

Understanding and effectively estimating urban evapotranspiration is important for water resource management and predicting the impacts of urban ET as increasing urban populations and shifting climate patterns affect watershed dynamics and availability of fresh water. The Middle Rio Grande basin is a water scarce region, and exploring all water conservation opportunities is important for future water sustainability. The results of this study will be used to support a larger water balance model for the Middle Rio Grande basin by providing a time series of urban ET from 1993-2015. The broader model will be used for future water resource decision making including the impacts of urban water conservation in water scarce regions.

Urban water conservation and management is crucial for protecting water resources in water scarce regions and ensuring that fresh water will be available for future use. Urban ET makes up more than half of urban water use and is an important component of the water cycle. Improving the accuracy of urban ET estimation methods and providing accurate estimates of urban ET for semi-arid to arid environments is important for urban water sustainability, especially when freshwater depletion in these regions is a possibility.

Urban ET was estimated for El Paso, TX, US; Las Cruces, NM, US and Ciudad Juarez, $\mathrm{CH}, \mathrm{MX}$ with the assumption that the main drivers for evapotranspiration are vegetation and bare soil, open water, infrastructure losses and evaporative cooling. Vegetation and bare soil ET is the largest ET component for each city and will be the most effective area of focus for future urban water conservation. Understanding the amount of water lost to ET for each driver is important for understanding how water is 
used for each city and where water conservation efforts can be most effective. Multiple methods of ET estimation were used to provide average annual ET estimates. Overall, the ET method estimates were similar for each city, with varying degrees of each other, and can be used to separate overall ET components.

On average, water lost to urban ET is between 50 to $63 \%$ of total urban water demand for the study area. Previous research suggests that outdoor water use accounts for $50 \%$ to $70 \%$ of urban water use in semi-arid regions in the southwestern United States (DeOreo, 2011; Litvak et al., 2016; Mini et al., 2014) and urban landscaping accounts for $40 \%$ to $70 \%$ of residential water use (St. Hilaire et al., 2008). Estimates from previous research on urban water use are similar to the results of the current study.

Average urban ET including precipitation is $500 \mathrm{~mm}$ annually for the study area. Previous research on agricultural ET in the Middle Rio Grande basin estimates an average annual ET for pecan crops as 498 to 1,259 mm (Samani, et al., 2000), 386 to $1217 \mathrm{~mm}$ for Alfalfa and 350 to $879 \mathrm{~mm}$ for cotton (Ahadi et al., 2013). Average annual reservoir evaporation for the Middle Rio Grande basin is $2450 \mathrm{~mm}$ yr-1 based on annual evaporation from Caballo and Elephant Butte Reservoirs, 1993 to 2015 (NOAA, n.d.), and the US Bureau of Reclamation suggested pan coefficient of 0.70. Reporting ET in $\mathrm{mm}$ allows for comparison of the intensity of water demand between different water use types and provides a means to scale urban ET to urban areas with similar climates based on land surface areas. 
While the results of the current study appear robust based on the relative agreement between methods, there are sources of uncertainty that may need to be addressed in future research. The fate of water from infrastructure losses in semi-arid and arid environments is unclear and further research is necessary to determine the magnitude of losses that contribute to urban ET. SSEBop remote sensing results have been validated for agricultural and natural area estimates of ET but are not commonly used for estimates of urban ET. For this study, it was assumed that the methods used to derive ET from satellite imagery were also applicable to urban landscapes. The complexity of water distribution within cities and the urban boundaries used to capture urban ET were ambiguous and added to the uncertainties with vegetation and bare soil estimates. The complexity of water distribution and evaporative use for urban water sectors led to uncertainty with consumptive use, especially in El Paso due to gaps in water utility data. Future research is necessary to address these uncertainties.

The methods used to estimate urban ET for this study have been applied to three cities that vary substantially in size and population with relative agreement for each city. Water use per capita is significantly larger in Las Cruces and El Paso than in Ciudad Juarez, which has the largest overall population. ET rates for El Paso and Las Cruces are similar on a per capita basis, which helps to quantify the difference in water use between the United States and Mexico. Observing differences in water use and evapotranspirative losses between cities suggests that water use implications may be different between the United States and Mexico, and the focus of water conservation and management plans for this region may need to adjusted accordingly. Although the results of this study use data 
from specific cities that may have unique characteristics, the relative agreement between methods suggest that they are transportable and can provide ET estimates for urban areas with similar climates. 


\section{Reference List}

1. Ahadi, R., Samani, Z., \& Skaggs, R. (2013). Evaluating on-farm irrigation efficiency across the watershed: A case study of New Mexico's Lower Rio Grande Basin. Agricultural Water Management, 124, 52-57. doi:

10.1016/j.agwat.2013.03.010

2. Al-Kofahi, S. D., Vanleeuwen, D. M., Samani, Z. A., \& Hilaire, R. S. (2012). Water Budget Calculator Created for Residential Urban Landscapes in Albuquerque, New Mexico. Journal of Irrigation and Drainage Engineering, 138(6), 525-533. doi:10.1061/(asce)ir.1943-4774.0000439

3. Allen, R. G., Pereira, L. S., Howell, T. A., \& Jensen, M. E. (2011). Evapotranspiration information reporting: I. Factors governing measurement accuracy. Agricultural Water Management,98(6), 899-920. doi:

10.1016/j.agwat.2010.12.015

4. Anderson, C. A., \& Vivoni, E. R. (2016). Impact of land surface states within the flux footprint on daytime land-atmosphere coupling in two semiarid ecosystems of the Southwestern U.S. Water Resources Research,52(6), 4785-4800. doi:10.1002/2015wr018016

5. Bisbee, D. (2010). Technology Evaluation Report: The CooleradoTM. Sacramento, California: Customer Advanced Technologies Program, Sacramento Municipal Utilities District. Retrieved on June 20, 2018, from 
https://www.smud.org//media/Documents/Business...and.../coolerado-newreport.ashx

6. Cabrera, R., Wagner, K., \& Wherley, B. (2013). An evaluation of urban landscape water use in Texas. Texas Water Journal, 4(2), 14-27. Retrieved March 20, 2018 from https://journals.tdl.org/twj/index.php/twj/article/view/6992.

7. Cervera Gómez, Luis Ernesto. (2007). Indicators of sustainable water use in Ciudad Juárez, Chihuahua. Border studies, 8 (16), 9-41. Retrieved on June 22, 2019, from http://www.scielo.org.mx/scielo.php?script=sci_arttext\&pid=S0187$\underline{69612007000200001 \& \operatorname{lng}=\text { es\&tlng=es. }}$.

8. Chavez, Octavio E. (2000). Mining of Internationally Shared Aquifers: The El Paso-Juarez Case, 40 Nat. Resources J. 237. Available at: https://digitalrepository.unm.edu/nrj/vol40/iss2/5.

9. Cleugh, H., Bui, E., Mitchell, V., Xu, J., Grimmond, C., Simon, D. (2005). Evapotranspiration in Urban Water Balance Models: A Methodological Framework. MODSIM 2005 International Congress on Modelling and Simulation. Modelling and Simulation Society of Australia and New Zealand. 170-176.

10. Council of State Governments (CSG). (2018). Water Usage in the West. Retrieved on July 20, 2019 from https://www.csgwest.org/policy/WesternWaterUsage.aspx. 
11. Diaz, R. (2018). Personal Communication. Las Cruces Water Utility Data, Water Audits, Wastewater Data.

12. DeOreo, W., Mayer, P., Martien, L., Hayden, M., Funk, A., Kramer-Duffield, M., Davis, R., Henderson, J., Raucher, B., Gleick, P., Heberger, M., Sanchez, F., McNulty, A. (2011). California single-family water use efficiency study. Report prepared for the California Department of Water Resources.

13. Desarrollo. (n.d.). Información Climatológica. Retrieved on January 20, 2019, from http://smn.cna.gob.mx/es/component/content/article?id=42.

14. Food and Agriculture Organization of the United Nations. (2019). Retrieved on July 09, 2019, from http://www.fao.org/publications/en/.

15. Gobierno de MÉXICO Información Climatológica. (n.d.). Retrieved January 20, 2017, from https://smn.conagua.gob.mx/es/component/content/article?id=42.

16. Gobierno de MEXICO. (2015). Cuidemos Y Valoremos El Agua Que Mueve A Mexico. Dia Mundial del Agua. Retrieved on January 3, 2019, from www.conagua.gob.mx/CONAGUA07/.../carrera_agua_2015.pdf

17. Grimmond, C. S. B., and T. R. Oke (1999). Evapotranspiration rates in urban areas, Impacts of Urban Growth on Surface Water and Groundwater Quality, Proceedings of IUGG 99 Symposium HS5, Birmingham, IAHS Publ. 259, pp. 235-243, IAHS Publ., Wallingford, Oxfordshire, U. K. 
18. Hargreaves, G. H., \& Samani, Z. A. (1985). Reference Crop Evapotranspiration from Temperature. Applied Engineering in Agriculture, 1(2), 96-99. doi:10.13031/2013.26773

19. Henggeler, J.C., Samani, Z.A., Flynn, M.S., and Zeitler, J.W. (1996). Evaluation of Various Evapotranspiration Equations for Texas and New Mexico. Proc., Int. Conf. on Evapotranspiration and Irrigation Scheduling, Irrigation Association International, San Antonio, TX, 962-967.

20. Hermitte S.M., \& Mace R.E. (2012). The grass is always greener ... Outdoor residential water use in Texas. Technical Note 12-01. Austin, Texas: Texas Water Development Board. 43 p.

21. Herrera Sosa, Luis \& Gomez-Azpeitia, Luis Gabriel. (2008). Assessment of Bioclimatic Applications in Buildings and the Consequent Reduction in Water Consumption when Using Evaporative Cooling Systems. PLEA 2008 - 25th Conference on Passive and Low Energy Architecture, Dublin, 22nd to 24th October 2008.

22. Hutchison, W.R. (2006). Groundwater management in El Paso, Texas. ETD Collection for University of Texas, El Paso. AAI3214009. Retrieved July 2, 2019 from https://digitalcommons.utep.edu/dissertations/AAI3214009

23. Jiang, Y., \& Weng, Q. (2016). Estimation of hourly and daily evapotranspiration and soil moisture using downscaled LST over various urban surfaces. GIScience \& Remote Sensing, 54(1), 95-117. doi:10.1080/15481603.2016.1258971 
24. Karpiscak, M.M., Babcock, T.M., France, G.W., Zauderer, J., Hopf, S.B. \& Foster, K.E. (1998). Evaporative cooler water use in Phoenix. Journal - American Water Works Association, 90: 121-130. doi:10.1002/j.1551-8833.1998.tb08415.x.

25. Kim, H., \& Kaluarachchi, J. J. (2018). Developing an Integrated Complementary Relationship for Estimating Evapotranspiration. Natural Resources,09(04), 89109. doi:10.4236/nr.2018.94007

26. Kurc, S. A., \& Small, E. E. (2004). Dynamics of evapotranspiration in semiarid grassland and shrubland ecosystems during the summer monsoon season, central New Mexico. Water Resources Research,40(9). doi:10.1029/2004wr003068

27. Litvak, E., Bijoor, N. S., \& Pataki, D. E. (2013). Adding trees to irrigated turfgrass lawns may be a water-saving measure in semi-arid environments. Ecohydrology. doi:10.1002/eco.1458

28. Litvak, E., Manago, K. F., Hogue, T. S., \& Pataki, D. E. (2017). Evapotranspiration of urban landscapes in Los Angeles, California at the municipal scale. Water Resources Research,53(5), 4236-4252. doi:10.1002/2016wr020254

29. Litvak, E., Mccarthy, H. R., \& Pataki, D. E. (2017). A method for estimating transpiration of irrigated urban trees in California. Landscape and Urban Planning, 158, 48-61. doi: 10.1016/j.landurbplan.2016.09.021

30. Litvak, E., \& Pataki, D. E. (2016). Evapotranspiration of urban lawns in a semiarid environment: An in-situ evaluation of microclimatic conditions and watering 
recommendations. Journal of Arid Environments, 134, 87-96. doi:

10.1016/j.jaridenv.2016.06.016

31. Liu, W, Hong, Y, Khan, SI, Huang, M, Vieux, B, Caliskan, S, Grout, T. (2010). Actual evapotranspiration estimation for different land use and land cover in urban regions using Landsat 5 data. Journal of Applied Remote Sensing 4: 041873- 14.

32. Martínez Arroyo, R.R., Salas Plata Mendoza, J.A., Quevedo Urías, H. (2015). Water Consumption and Waste of Residential Evaporative Systems. Scientific and Technological Culture, [S1], n. ISSN 2007-0411. Retrieved January 20, 2019, from http://erevistas.uacj.mx/ojs/index.php/culcyt/article/view/429.

33. Mcmahon, T. A., Peel, M. C., Lowe, L., Srikanthan, R., \& Mcvicar, T. R. (2013). Estimating actual, potential, reference crop and pan evaporation using standard meteorological data: A pragmatic synthesis. Hydrology and Earth System Sciences, 17(4), 1331-1363. doi:10.5194/hess-17-1331-2013

34. Mini, C., Hogue, T., \& Pincetl, S. (2014). Estimation of residential outdoor water use in Los Angeles, California. Landscape and Urban Planning, 127, 124-135. doi: 10.1016/j.landurbplan.2014.04.007

35. Mitchell, V.G., R.G. Mein and T.A. McMahon (2001), Modelling the urban water cycle, Journal of Environmental Modelling and Software, 16, 615-629.

36. Multi-Resolution Land Characteristics Consortium (n.d.). Retrieved on July 15, 2019, from https://www.mrlc.gov/data/type/land-cover 
37. National Centers for Environmental Information. (n.d.). Climate Data Online. Retrieved July 07, 2018, from https://www.ncdc.noaa.gov/cdo-web/.

38. National Water Commission. (2017). Statistics on Water in Mexico, 2017 Edition. Ministry of Environment and Natural Resources. Retrieved on August 15, 2019, from sina.conagua.gob.mx/publicaciones/EAM_i_2017.pdf.

39. New Mexico Office of the State Engineer Water Use and Conservation Programs. (n.d.). Retrieved January 04, 2018, from https://www.ose.state.nm.us/WUC/

40. Nouri, H., Beecham, S., Anderson, S., \& Nagler, P. (2014). High Spatial Resolution WorldView-2 Imagery for Mapping NDVI and Its Relationship to Temporal Urban Landscape Evapotranspiration Factors. Remote Sensing,6(1), 580-602. doi:10.3390/rs6010580

41. Nouri, H., Glenn, E., Beecham, S., Boroujeni, S. C., Sutton, P., Alaghmand, S., \& Nagler, P. (2016). Comparing Three Approaches of Evapotranspiration Estimation in Mixed Urban Vegetation: Field-Based, Remote Sensing-Based and Observational-Based Methods. Remote Sensing,8(6), 492-506. doi:10.3390/rs8060492

42. Pataki, D. E., Boone, C. G., Hogue, T. S., Jenerette, G. D., Mcfadden, J. P., \& Pincetl, S. (2011). Socio-ecohydrology and the urban water challenge. Ecohydrology,4(2), 341-347. doi:10.1002/eco.209

43. PdnMapa Interactive Mapping. (n.d.). Retrieved January 01, 2018, from http://gis.elpasotexas.gov/pdnmapajs/ 
44. Penman, H. L. (1948). Natural evaporation from open water, bare soil and grass. Proceedings of the Royal Society of London. Series A. Mathematical and Physical Sciences, 193(1032), 120-145. doi:10.1098/rspa.1948.0037

45. Peters, E. B., Hiller, R. V., \& Mcfadden, J. P. (2011). Seasonal contributions of vegetation types to suburban evapotranspiration. Journal of Geophysical Research,116(G1). doi:10.1029/2010jg001463

46. Qiu, G., Li, H., Zhang, Q., Chen, W., Liang, X., \& Li, X. (2013). Effects of Evapotranspiration on Mitigation of Urban Temperature by Vegetation and Urban Agriculture. Journal of Integrative Agriculture, 12(8), 1307-1315. doi:10.1016/s2095-3119(13)60543-2

47. Qiu, G., Tan, S., Wang, Y., Yu, X., \& Yan, C. (2017). Characteristics of Evapotranspiration of Urban Lawns in a Sub-Tropical Megacity and Its Measurement by the 'Three Temperature Model Infrared Remote Sensing' Method. Remote Sensing,9(5), 502. doi:10.3390/rs9050502

48. Raoufi, R., \& Beighley, E. (2017). Estimating Daily Global Evapotranspiration Using Penman-Monteith Equation and Remotely Sensed Land Surface Temperature. Remote Sensing, 9(11), 1138. doi:10.3390/rs9111138

49. Reitz, M., Senay, G., \& Sanford, W. (2017). Combining Remote Sensing and Water-Balance Evapotranspiration Estimates for the Conterminous United States. Remote Sensing, 9(12), 1181-1197. doi:10.3390/rs9121181 
50. Salas Plata Mendoza, Jorge A. (2006). The Water Utilities of Ciudad Juarez (JMAS), Chihuahua, Mexico: Water Management and the Modality of Decentralization. Paper 63. http://opensiuc.lib.siu.edu/ucowrconfs_2006/63.

51. Samani, Z. (2000). Estimating Solar Radiation and Evapotranspiration Using Minimum Climatological Data. Journal of Irrigation and Drainage Engineering, 126(4), 265-267. doi:10.1061/(asce)0733-9437(2000)126:4(265)

52. Samani, Z., Bawazir, A. S., Bleiweiss, M., Skaggs, R., Longworth, J., Tran, V. D., \& Pinon, A. (2009). Using remote sensing to evaluate the spatial variability of evapotranspiration and crop coefficient in the lower Rio Grande Valley, New Mexico. Irrigation Science, 28(1), 93-100. doi:10.1007/s00271-009-0178-8

53. Samani, Z., Sammis, T., Skaggs, R., Alkhatiri, N., \& Deras, J. (2005). Measuring On-Farm Irrigation Efficiency with Chloride Tracing under Deficit Irrigation. Journal of Irrigation and Drainage Engineering, 131(6), 555-559. doi:10.1061/(asce)0733-9437(2005)131:6(555)

54. Senay, G. B. (2018). Satellite Psychrometric Formulation of the Operational Simplified Surface Energy Balance (SSEBop) Model for Quantifying and Mapping Evapotranspiration. Applied Engineering in Agriculture,34(3), 555-566. doi:10.13031/aea.12614

55. Senay, Gabriel et al. (2018). Upper Rio Grande River Basin SSEBop Monthly Sum Actual Evapotranspiration 1984-2015, USGS Earth Resources Observation and Science (EROS) Center, Sioux Falls, South Dakota 
56. Servicios de Ingeniería e Informática. (2013). Actualización del Plan Maestro para el Mejoramiento de los Servicios de Agua Potable, Alcantarillado y Saneamiento en Juárez, Chihuahua. [Update of the Master Plan for the Improvement of Drinking Water, Sewerage and Sanitation Services in Juárez, Chihuahua]. Informe Final Junio, 2013. Juarez, Chihuahua, Mexico.

57. Sheng, Z., \& Devere, J. (2005). Understanding and managing the stressed Mexico-USA transboundary Hueco bolson aquifer in the El Paso del Norte region as a complex system. Hydrogeology Journal, 13(5-6), 813-825. doi:10.1007/s10040-005-0451-8

58. Singh, R., \& Senay, G. (2015). Comparison of Four Different Energy Balance Models for Estimating Evapotranspiration in the Midwestern United States. Water, 8(1), 9-27. doi:10.3390/w8010009

59. Skaggs, R. K., \& Samani, Z. (2005). Farm size, irrigation practices, and on-farm irrigation efficiency. Irrigation and Drainage, 54(1), 43-57. doi:10.1002/ird.148

60. Stefano, C. D., \& Ferro, V. (1997). Estimation of Evapotranspiration by Hargreaves Formula and Remotely Sensed Data in Semi-arid Mediterranean Areas. Journal of Agricultural Engineering Research,68(3), 189-199. doi:10.1006/jaer.1997.0166

61. Texas Natural Resources Information System DataHub. (n.d.). Retrieved December 01, 2017, from https://data.tnris.org/. 
62. Texas Water Development Board. (2017). 2017 State Water Plan. Retrieved January 05, 2019, from http://www.twdb.texas.gov/waterplanning/swp/2017/index.asp.

63. Texas Water Development Board. Information on Precipitation and Gross Lake Evaporation Data. (n.d.). Retrieved July 07, 2017, from http://www.twdb.texas.gov/surfacewater/conditions/evaporation/evapinfo/index.a sp.

64. Trezza, R., Allen, R., \& Tasumi, M. (2013). Estimation of Actual Evapotranspiration along the Middle Rio Grande of New Mexico Using MODIS and Landsat Imagery with the METRIC Model. Remote Sensing,5(10), 53975423. doi:10.3390/rs5105397

65. United Nations. (2018) Synthesis Report 2018 on Water and Sanitation. Retrieved August 01, 2019, from https://www.unwater.org/publication categories/sdg-6synthesis-report-2018-on-water-and-sanitation/.

66. United Nations Department of Economic and Social Affairs. (2019). The Sustainable Development Goals Report. Retrieved August 01, 2019, from https://unstats.un.org/sdgs/report/2019/.

67. United Nations Population Division. (2019). United Nations Department of Economic and Social Affairs. Retrieved August 01, 2019 from https://www.un.org/en/development/desa/population/index.asp. 
68. USDA Natural Resources Conservation Service: Geospatial Data Gateway. (n.d.). Retrieved December 01, 2017, from https://datagateway.nrcs.usda.gov/.

69. USGS. (n.d.). USGS EarthExplorer. Retrieved July 07, 2017, from https://earthexplorer.usgs.gov/.

70. USGS. (2018). Water Use Data for Texas. National Water Information System: Web Interface. Retrieved on July 20, 2019 from https://waterdata.usgs.gov/tx/nwis/water_use/.

71. Walker, S., Capt, T. (2017). Personal Communication. El Paso Water Utility Water and Wastewater Data.

72. Western Regional Climate Center. (n.d.). Retrieved January 20, 2017, from https://wrcc.dri.edu/Climate/summaries.php. 


\section{A Figures and Tables}

\section{A.1 Figures}

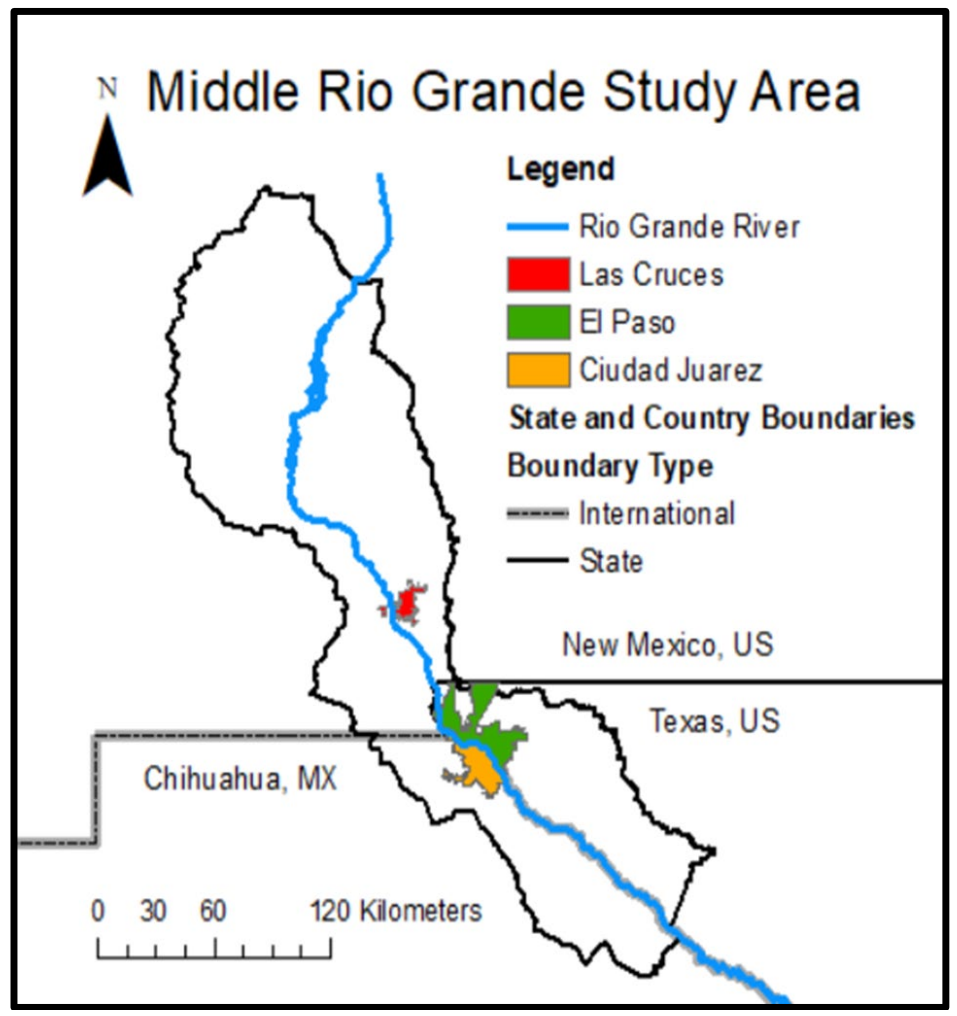

Figure 1. Middle Rio Grande study area including the cities of Las Cruces, New Mexico, US; El Paso, Texas, US; and Ciudad Juarez, Chihuahua, MX. 


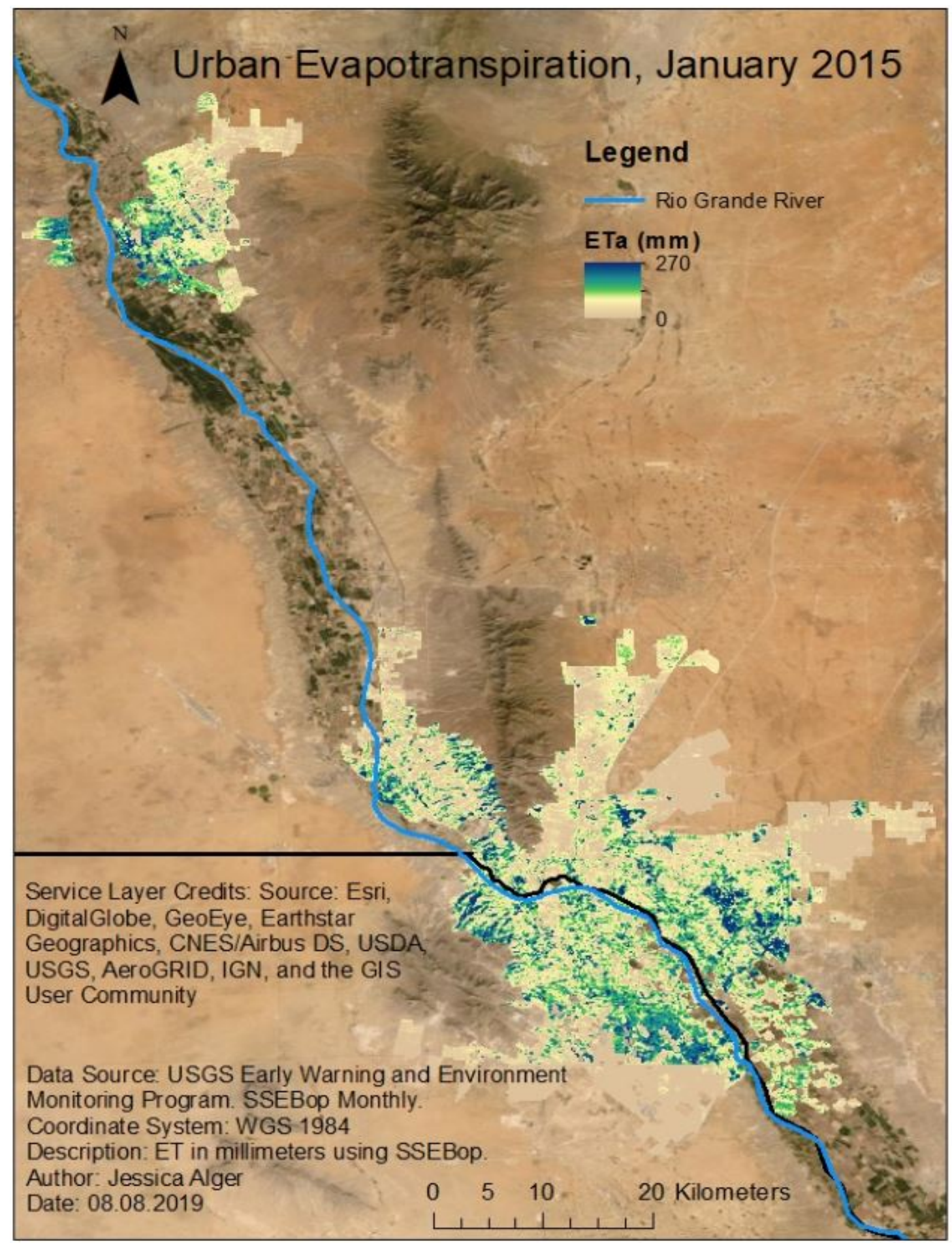

Figure 2. Urban ET map for January, 2015, using the Operational Simplified Surface Energy Balance (SSEBop) developed by the USGS for the Rio Grande basin. ET maps obtained from the USGS were clipped to the city borders for Las Cruces, NM, US; El Paso, TX, US; and Ciudad Juarez, CH, MX to obtain urban ET for the Middle Rio Grande basin study area. 


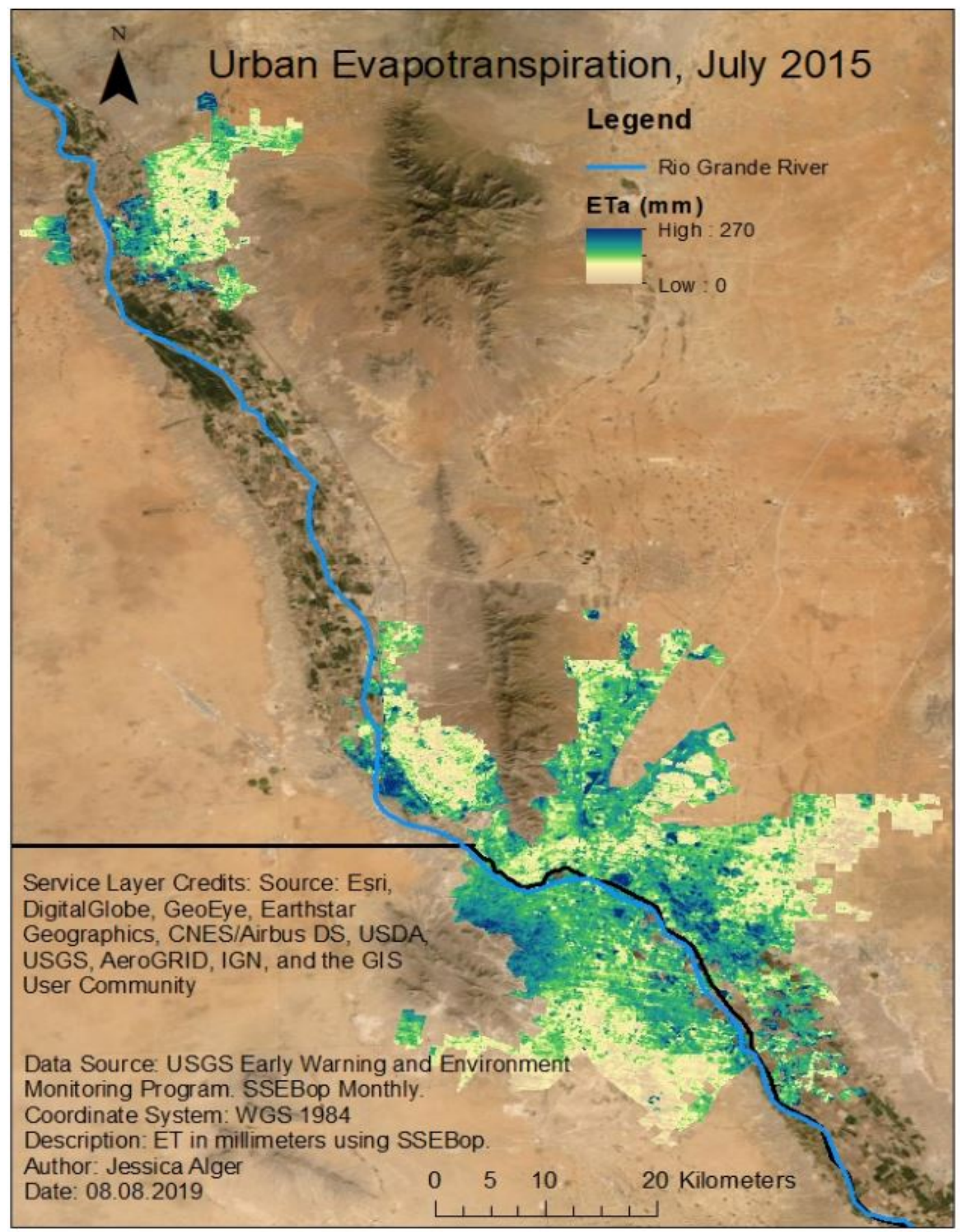

Figure 3. Urban ET map for July, 2015, using the Operational Simplified Surface Energy Balance (SSEBop) developed by the USGS for the Rio Grande basin. ET maps obtained from the USGS were clipped to the city borders for Las Cruces, NM, US; El Paso, TX, US; and Ciudad Juarez, CH, MX to obtain urban ET for the Middle Rio Grande basin study area. 


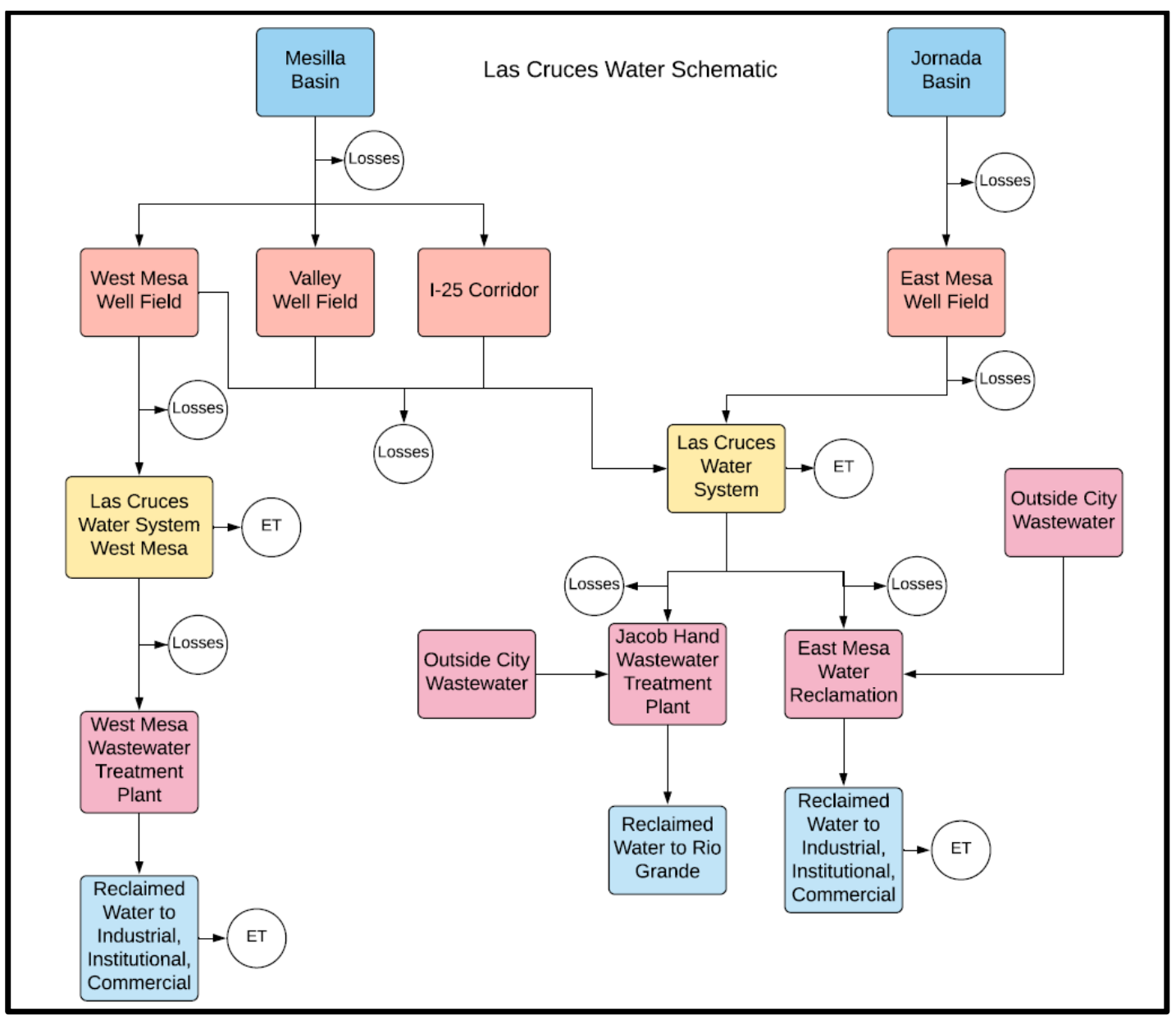

Figure 4. Simplified water pathway for Las Cruces, NM, USA, showing how water is traced from the urban water source to the wastewater treatment plant effluent use. 


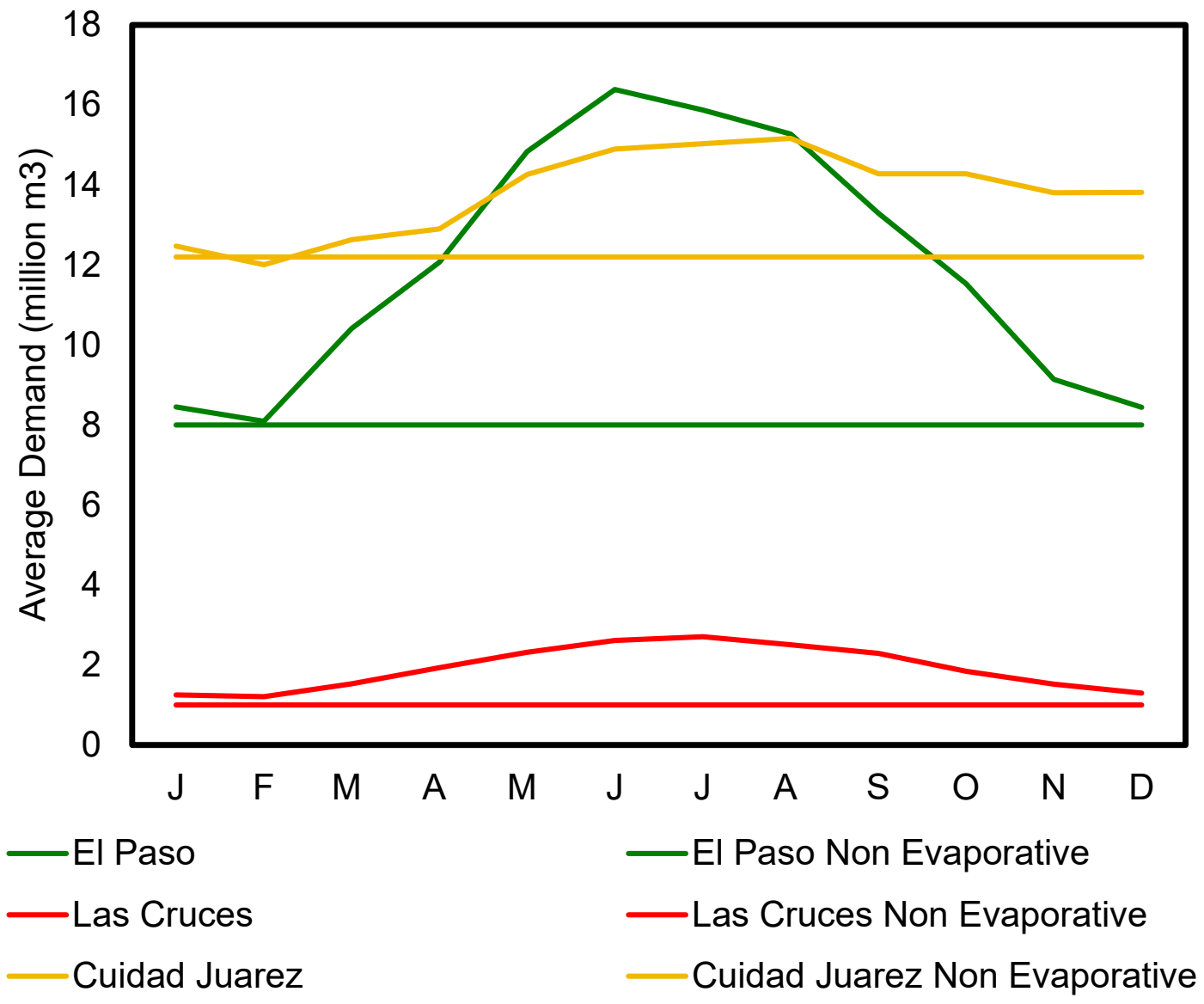

Figure 5. Average total urban water demand and non-evapotranspirative water demand, million cubic meters per month from 1993-2015. 


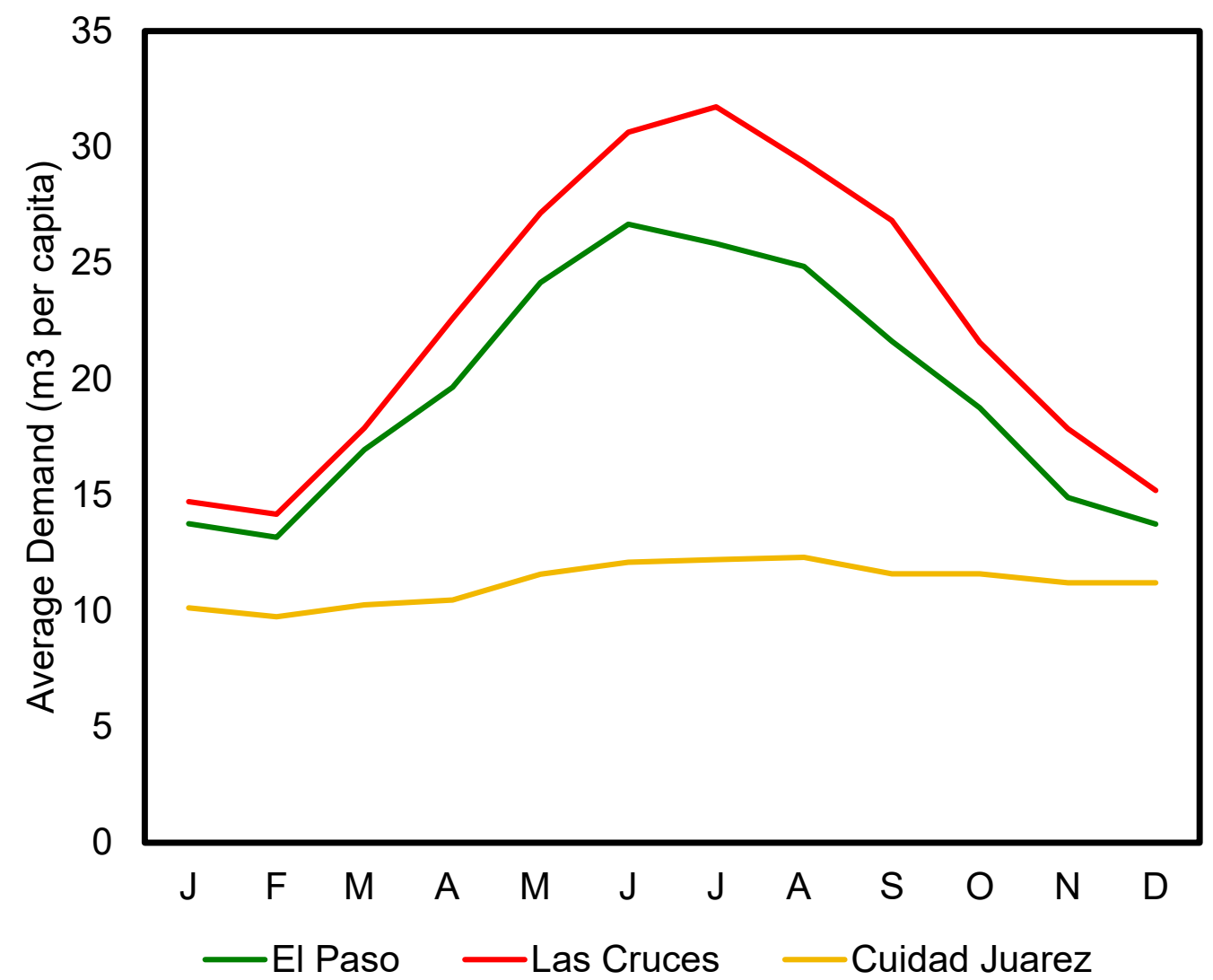

Figure 6. Average urban water demand, cubic meters per capita per month 1993-2015. 


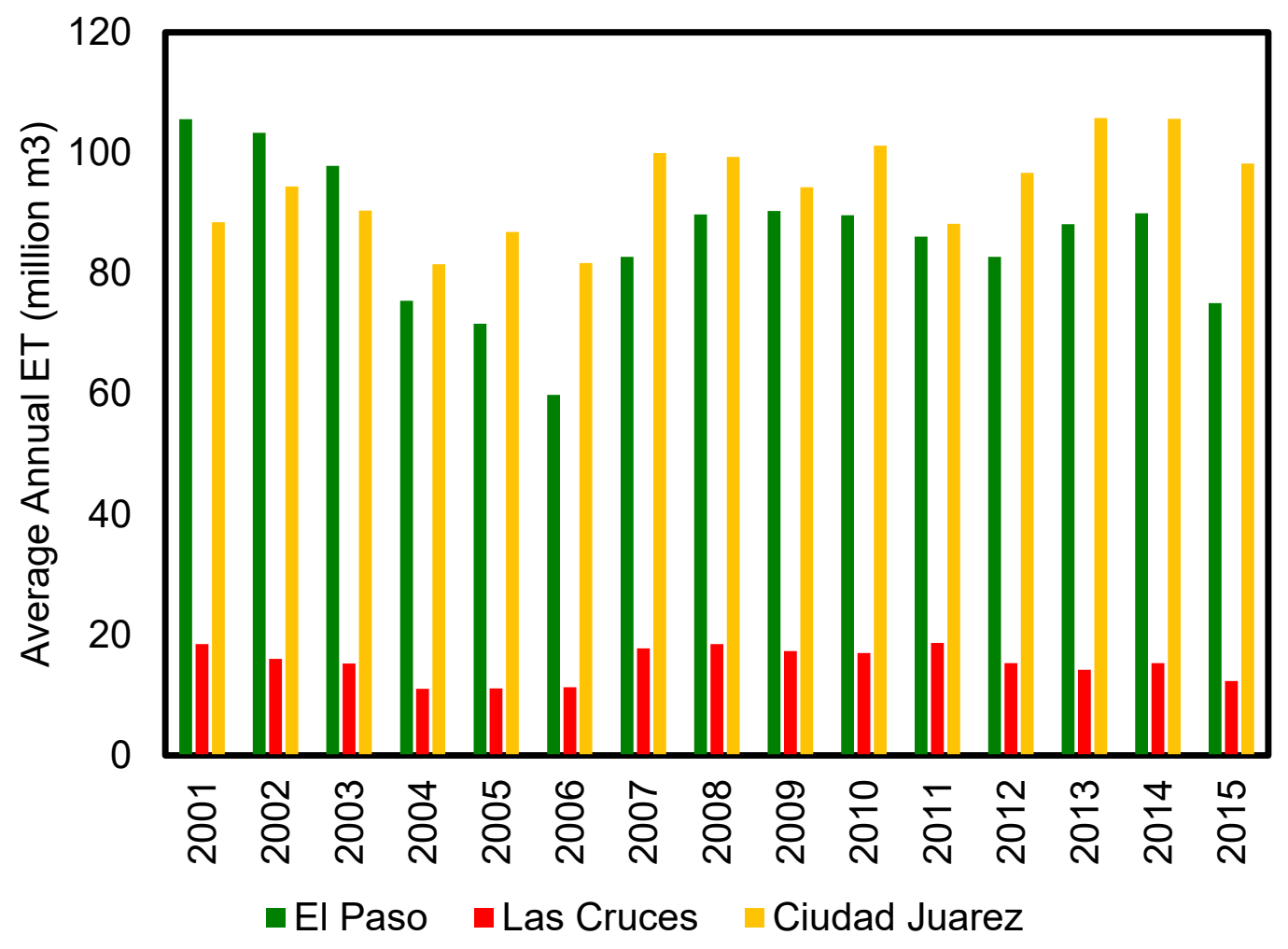

Figure 7. Annual evapotranspiration comparison in million $\mathrm{m} 3$ for each city, 2001-2015. To compare annual changes in urban ET, average ET from all methods was used. ET totals include ET from infrastructure losses. 


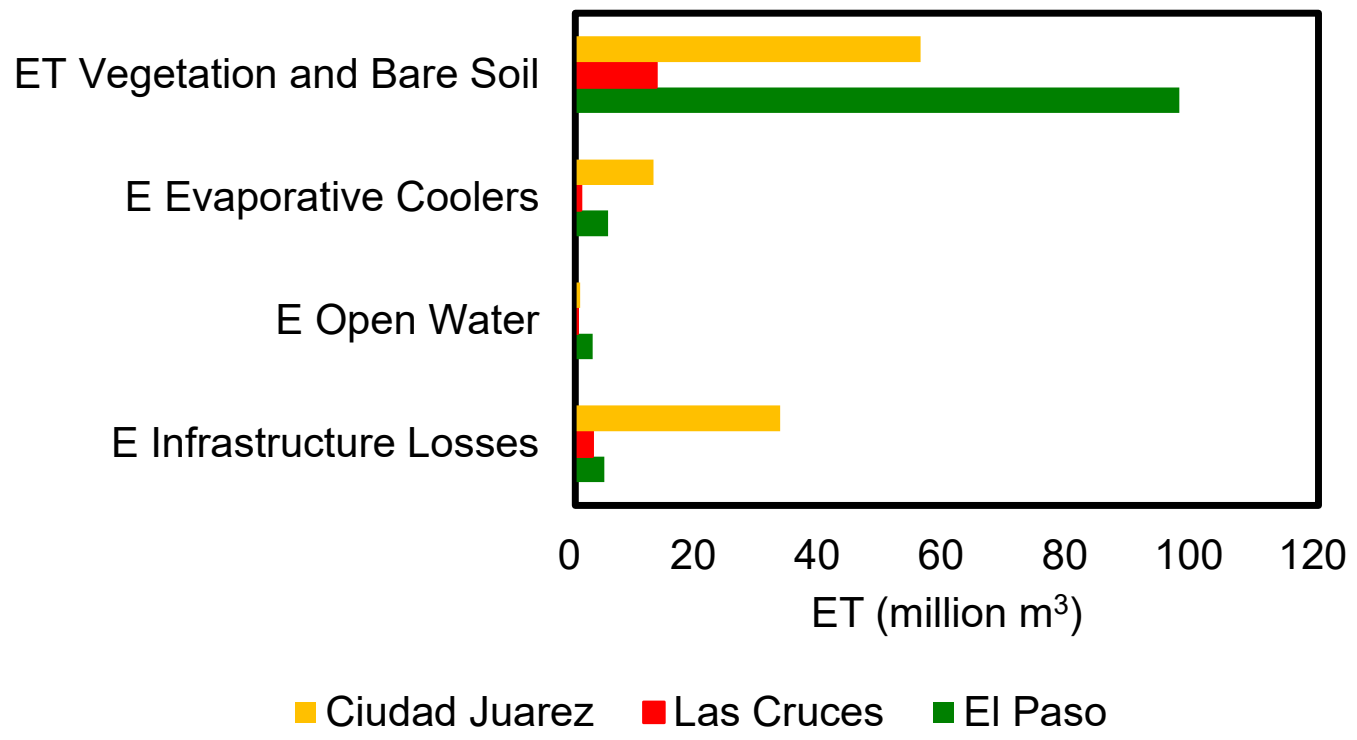

Figure 8. Average annual evapotranspiration comparison of urban ET components in million cubic meters, 1993-2015. 


\section{A.2 Tables}

Table 1. Summary of climate and demographic data for each city in the Middle Rio Grande study area.

\begin{tabular}{lcccc}
\hline \multicolumn{1}{c}{ City } & $\begin{array}{c}\text { Average } \\
\text { Temperature } \\
\text { Range } \\
\left({ }^{\circ} \text { Celsius }\right)\end{array}$ & $\begin{array}{c}\text { Average } \\
\text { Precipitation } \\
\text { (mm) }\end{array}$ & $\begin{array}{c}\text { Areas } \\
\text { According } \\
\text { to Political } \\
\text { Boundaries } \\
\left(\mathrm{km}^{2}\right)\end{array}$ & Population \\
\hline Las Cruces, NM, US & 8.5 to 25.4 & 236 & 198 & 101,712 \\
El Paso, TX, US & 11.0 to 25.3 & 236 & 664 & 683,577 \\
Ciudad Juarez, CH, MX & 9.0 to 25.9 & 235 & 321 & $1,423,166$ \\
\hline
\end{tabular}

Sources: Temperature (NOAA), Precipitation (NOAA \& Government of MX Meteorological Service), Area (US Census Bureau \& Google Maps) \& Population (US Census Bureau, 2017 \& The Borderplex Alliance, 2016)

Table 2. Average annual comparison of ET methods in million cubic meters, 1993-2015. Lower range of ET assumes zero evaporation from infrastructure losses and upper ranges assumes $100 \%$ evaporation from infrastructure losses.

\begin{tabular}{lccc}
\hline \multicolumn{1}{c}{ Method } & $\begin{array}{c}\text { El Paso, } \\
\text { TX, US }\end{array}$ & $\begin{array}{c}\text { Las Cruces, } \\
\text { NM, US }\end{array}$ & $\begin{array}{c}\text { Ciudad Juarez, } \\
\text { CH, MX }\end{array}$ \\
\hline Total Components ET & $106-110$ & $14-17$ & $69-102$ \\
Consumptive Use ET & $80-84$ & $11-14$ & $61-96$ \\
Seasonal Water Use ET & $86-91$ & $11-14$ & $62-97$ \\
Average ET & $91-95$ & $13-15$ & $64-98$ \\
\hline
\end{tabular}


Table 3. Average annual ET and average overall water demand comparison in cubic meters per capita, 1993-2015.

\begin{tabular}{lccc}
\hline \multicolumn{1}{c}{ Method } & $\begin{array}{c}\text { El Paso, } \\
\text { TX, US }\end{array}$ & $\begin{array}{c}\text { Las Cruces, } \\
\text { NM, US }\end{array}$ & $\begin{array}{c}\text { Ciudad Juarez, } \\
\text { CH, MX }\end{array}$ \\
\hline Total Components ET & $175-183$ & $174-208$ & $59-86$ \\
Consumptive Use ET & $131-139$ & $134-168$ & $46-72$ \\
Seasonal Water Use ET & $142-149$ & $136-169$ & $47-74$ \\
Average Water Demand & 235 & 283 & 135 \\
\hline
\end{tabular}

Table 4 Average annual comparison of ET rates for each method in millimeters, 19932015. Lower range of ET assumes zero evaporation from infrastructure losses and upper ranges assumes $100 \%$ evaporation from infrastructure losses.

\begin{tabular}{lccc}
\hline \multicolumn{1}{c}{ Method } & $\begin{array}{c}\text { El Paso, } \\
\text { TX, US }\end{array}$ & $\begin{array}{c}\text { Las Cruces, } \\
\text { NM, US }\end{array}$ & $\begin{array}{c}\text { Ciudad Juarez, } \\
\text { CH, MX }\end{array}$ \\
\hline & & & \\
Total Components ET & $281-295$ & $138-179$ & $304-498$ \\
Consumptive Use ET & $247-262$ & $161-202$ & $328-519$ \\
Seasonal Water Use ET & $267-282$ & $163-204$ & $337-527$ \\
Average ET & $265-280$ & $154-195$ & $323-515$ \\
\hline
\end{tabular}

